\title{
GISEA: an Italian biological agents registry in rheumatology
}

\section{II registro Italiano del Gruppo GISEA}

\author{
G. Lapadula, G. Ferraccioli, C. Ferri, L. Punzi, F. Trotta on behalf of GISEA ${ }^{1}$ \\ ${ }^{1}$ Gruppo Italiano di Studio sulle Early Arthritides (GISEA): Bambara M.L. Nerona), Cantini F. (Prato), \\ Ferraccioli G. (Roma), Ferri C. (Modena), Foti R. (Catania), Galeazzi M. (Siena), Gerli R. (Perugia), \\ Giacomelli R. (L’Aquila), Gorla R. (Brescia), Grassi W. (Jesi), Lapadula G. (Bari), Marchesoni A. (Milano), \\ Mathieu A. (Cagliari), Olivieri I. (Potenza), Passiu G. (Sassari), Punzi L. (Padova), Salvarani C. (Reggio Emilia), \\ Sarzi-Puttini P. (Milano), Scarpa R. (Napoli), Triolo G. (Palermo), Trotta F. (Ferrara)
}

\section{RIASSUNTO}

Il registro GISEA è una banca dati istituita dal Gruppo Italiano per lo Studio di Early Arthritis (GISEA) nel 2008 e finanziata dall'associazione italiana dei pazienti reumatici (ANMAR-ONLUS). Il suo scopo è quello di fornire un follow-up a lungo termine di pazienti con malattie reumatiche che sono trattati con agenti biologici. In questo documento descriviamo il disegno e la metodologia usati per raccogliere i dati dei pazienti. Registriamo informazioni demografiche, decorso della malattia, cambiamenti di trattamento, includendo le ragioni del cambiamento e la durata di ciascuna terapia, le terapie concomitanti e gli eventi avversi. Queste informazioni sono disponibili ai membri del gruppo di studio attraverso un'interfaccia basata su web che consente richieste e presentazione di dati numerici, oltre a una rappresentazione grafica per apprezzare le tendenze. Quattordici centri italiani di reumatologia hanno partecipato contribuendo con pazienti alla banca dati. Al momento della scrittura di questo testo la banca dati include 5145 pazienti, prevalentemente donne (72\%) e con un'età media di 53 anni (intervallo 16-88).

Diagnosi: $3494(67,9 \%)$ con artrite reumatoide, $833(16,2 \%)$ con artrite psoriasica, $493(9,6 \%)$ con spondilite anchilosante, $307(5,9 \%)$ con spondiloentesoartrite indifferenziata, $14(0,3 \%)$ con artrite enteropatica e 4 $(0,1 \%)$ con spondilite successiva ad una artrite reattiva. I trattamenti biologici hanno incluso etanercept, infliximab, anakinra, adalimumab, abatacept, rituximab e tocilizumab. I pazienti sono stati seguiti per 10 anni; sul totale degli arruolati, 1927 pazienti (35.8\%) sono in follow-up da almeno 3 anni. Nel registro GISEA sono stati osservati in tutto 2926 eventi avversi, con 1171 (22\%) pazienti che ne hanno riportato almeno uno. Auspichiamo che l'analisi di questi dati accumulati consenta di approfondire la critica fase precoce dell'artrite reumatoide e renda possibile l'identificazione di profili clinici che predicano la responsività alla terapia.

Reumatismo, 2011; 63 (3): 155-164

\section{INTRODUCTION}

$\mathrm{R}$ egistries have been developed by a number of Rheumatology Societies in order to provide a clear-cut database concerning the occurrence of minor and major adverse events in patients treated with biological drugs. Although it is indisputable that randomised trials are useful for measuring efficacy under controlled conditions, they have well-known shortcomings in terms of the discovery of rare or late developing adverse events (1-9). Relying on the passive voluntary reporting of adverse events after a drug is introduced on the market also has its limitations (10), and questions concerning the efficacy of new drugs in routine clinical use cannot be answered by randomised clinical trials but only through the long-term observation of large representative groups of patients in a variety of clinical settings. Consequently, registries have been proposed for the longterm surveillance necessary to assure the safe and rational clinical use of the existing and future treatments available to rheumatologists (11).

GISEA (the Italian Group for the Study of Early Arthritis, see http://www.registrogisea.com) involves 21 Italian clinical centres
Indirizzo per la corrispondenza: Prof. Giovanni Lapadula Rheumatology Unit

Dept. Internal and Public Medicina (DiMIMP) Università degli Studi Aldo Moro - 70124 Bari c/o Az. Universitario-Ospedaliera Policlinico P.za Giulio Cesare, 11 - 70124 Bari E-mail: g.lapadula@reumbari.uniba.it 
and practices and has the aim of investigating the evolution of (poly)arthritides from their earliest manifestations by monitoring disease progression during treatment and promoting early diagnosis and treatment. Fourteen of the twenty one GISEA centres have contributed to build a registry whose aim is to collect the clinical and laboratory data of patients affected by inflammatory arthropathies treated with biological agents in order to evaluate the number and prevalence of adverse events related to their long-term use, establish the proportion of responders and their survival on therapy, identify the predictive factors and/or comorbidities modifying the outcome of biological therapy, and ascertaining the major risk factors for an inadequate response to the most widely used biological drugs.

This paper describes the design and methodology of the GISEA registry of Italian patients with (poly)arthritides treated with biological agents, which includes all of the patients monitored in GISEA referral centres regardless of the duration of their disease, and the preliminary data obtained.

\section{PATIENTS AND METHODS}

\section{GISEA registry}

In 2008, with the funding and support of the Italian Association of Rheumatic Patients (ANMAR - ONLUS), our group established a national database for monitoring the efficacy and safety of $\mathrm{TNF} \alpha$ blocking therapies, which were initially only used to treat early aggressive rheumatoid arthritis (RA). Subsequently, as new biological therapies entered the Italian market and their therapeutic indications were extended to other diseases, we also included patients taking these drugs for other types of arthritides. The participating centres represent a mix of small and large clinics or departments.

Survival on therapy is defined as the number of months from baseline (first administration) to the time of this analysis or treatment discontinuation (to switch to another drug or when the patients were lost to follow-up).
The protocol does not pre-establish the patients' assignment to a study drug. The drugs are prescribed in accordance with their Summaries of Product Characteristics (SmPCs) on the basis of the physicians' independent judgement and current clinical practice, thus clearly separating the decision to prescribe a certain treatment from inclusion in the registry. The patients do not undergo any additional diagnostic or monitoring procedures.

\section{Study population}

The patients consecutively attending each GISEA referral center are enrolled if they are diagnosed as having RA, psoriatic arthritis (PsA), ankylosing spondylitis (AS), enteroarthritis, undifferentiated spondyloarthritides) $(12,14)$. All of the subjects entered in the registry are required to meet the eligibility criteria and provide written consent to the use of their personal and healthrelated data.

\section{Inclusion criteria}

Patients are enrolled in the GISEA registry on the basis of the following inclusion criteria:

- an age of $>18$ years;

- written informed consent given before enrolment;

- a diagnosis of chronic inflammatory arthropathy as specified above;

- treatment with conventional diseasemodifying anti-rheumatic drugs (DMARDS) and/or biological agents in accordance with current national and international guidelines $(15,18)$ and usual standards of good clinical practice.

\section{Exclusion criteria}

Patients are excluded from the registry on the basis of the following criteria:

- an age of $<18$ years;

- refusal to participate in the study or sign the informed consent form;

- the presence of any of the contraindications listed in each drug's SmPC.

\section{Information retrieval}

When patients enter the registry, information is collected concerning their demo- 
graphic (age, gender, ethnicity, and present and past smoking status) and baseline disease characteristics, including diagnosis, duration and functional class, previous treatments (conventional DMARDS and/or biological agents), comorbidities, and the extra-articular manifestations of their rheumatic disease.

Subsequently, data concerning treatment, disease activity, response to therapy and adverse events are collected at pre-specified intervals from the time of diagnosis and stored by the investigator in a web-based limited-access database (Tab. I) (loaded on http://www.registrogisea.com) that allows the graphic and tabular representation of current and past disease activity and medication. Access to the database is protected by an identification procedure: the investigators are given their own user-IDs and passwords.

After signing a written informed consent form, each registry patient is assigned a centre-scpecific subject number, and the investigators can only access the relating to their own patients.

The database was created by CD Pharma Group S.r.l. (Milan, Italy), which is also responsible for data management.

\section{Assessment of disease activity and treatment response}

Disease activity is measured at baseline, six and 12 months after entry, and every year thereafter. All of the procedures described below (clinical, laboratory and imaging techniques) fall within the usual clinical management of rheumatic patients receiving biological therapy as per the current national and international guidelines.

Disease activity and treatment response are assessed using internationally established criteria.

a) Rheumatoid arthritis (Tab. Ia). The patients are monitored by means of:

1) the Disease Activity Score (DAS28) (19);

2) the individual components of the DAS-28: swollen joint count (SJC, 0-28), tender joint count (TJC, 0-28), erythrocyte sedimentation
Table I - GISEA registry: data collected at each time-point for RA patients (A) and SpA patients (B).

\begin{tabular}{|c|c|c|}
\hline (A) & Baseline visit (T0) & Follow-up visits \\
\hline Informed consent & $X$ & \\
\hline Demographical data & $x$ & \\
\hline Inclusion/exclusion criteria & $x$ & \\
\hline Anamnesis & $X$ & $X$ \\
\hline Physical examination & $x$ & $X$ \\
\hline Current therapy & $X$ & $X$ \\
\hline Laboratory tests, ESR, CRP & $x$ & $X$ \\
\hline RF, anti-CCP & $X$ & $x$ \\
\hline ANA, anti-dsDNA, anti-ENA & $x$ & $X$ \\
\hline $\mathrm{HAQ}$ & $X$ & $X$ \\
\hline DAS 28 & $x$ & $X$ \\
\hline Adverse events & $X$ & $X$ \\
\hline (B) & Baseline visit (T0) & Follow-up visits \\
\hline Informed consent & $x$ & \\
\hline Demographic data & $X$ & \\
\hline Inclusion/exclusion criteria & $X$ & \\
\hline Anamnesis & $X$ & $X$ \\
\hline Physical examination & $X$ & $X$ \\
\hline Current therapy & $X$ & \\
\hline Laboratory tests, ESR, CRP & $X$ & $x$ \\
\hline RF & $X$ & $X$ \\
\hline ANA, anti-dsDNA, anti-ENA & $X$ & $X$ \\
\hline TJC (0-68), SJC (0-66) & $x$ & $X$ \\
\hline BASDAI & $X$ & $X$ \\
\hline BASFI & $x$ & $X$ \\
\hline MASES index & $X$ & $X$ \\
\hline PASI & $X$ & $X$ \\
\hline Adverse events & $X$ & $X$ \\
\hline
\end{tabular}

rate (ESR), and patient-reported global health status (GH, VAS);

3) the simplified disease activity index (SDAI) and clinical disease activity index (CDAI) $(20,21)$;

4) the American College of Rheumatology (ACR) core set of outcome measures for rheumatoid arthritis (22); and

5) the Health Assessment Questionnaire (HAQ) (23) in order to monitor functional disability.

b) Ankylosing spondylitis, psoriatic arthritis and undifferentiated arthritis (Tab. Ib). As appropriate for each case, the patients are monitored by means of: 1) swollen joint count (SJC, 0-66) and tender joint count (TJC, 0-68), to include the cervical spine, ankles, feet 
and the distal interphalangeal joints of the hands and feet;

2) the assessment in the Ankylosing Spondylitis coreset (ASAS) (24);

3) the Bath Ankylosing Spondylitis Disease Activity Index (BASDAI) (25), the Bath Ankylosing Spondylitis Functional Index (BASFI) (26), the Bath Ankylosing Spondylitis Metrology Index (BASMI) (27), the Maastricht Ankylosing Spondylitis Enthesitis Score (MASES) (28), and the Psoriasis Area Severity Index (PASI) (29).

The laboratory data collected for each rheumatic patient are rheumatoid factor, Creactive protein, anti-cyclic-citrullinated protein antibodies, and the erythrocyte sedimentation rate.

All of the patients undergo the screening and follow-up procedures recommended in the current guidelines, including $\mathrm{Tb}, \mathrm{HBV}$, HCV screening and chest and pathological joints radiographs.

\section{Safety}

All adverse drug reactions were recorded and classified on the basis of their severity and causal relationship with the administered drugs.

\section{Pharmacoeconomic data}

Health-related quality of life (HRQoL) is assessed at baseline and every follow-up time-point using the EuroQoL (EQ-5D) questionnaire, a simple self-administered instrument that is designed to measure general health outcomes by generating a 5- domain profile (mobility, self-care, anxiety/depression, usual activities and pain/ discomfort) and an overall health-related quality of life score measured by means of a visual analogue scale (VAS); it is also a useful tool to derive cost/utility analyses. The EQ-5D is one of the most extensively validated measures for evaluating overall HRQoL in patients with inflammatory arthritis (30).

Negative effects on the working productivity of both patients and caregivers is measured as the amount of working time lost due to the disease.

\section{Ethical aspects}

This study is being performed in accordance with the principles of the Declaration of Helsinki and European and local rules of good clinical practice (GCP). All of the the procedures are part of the usual care of patients. The study was assessed and approved by the Ethics Committee and a
Figure 1 - Distribution of the $5145 \mathrm{Gl}-$ SEA patients among the 14 participating centres as of March 2010.

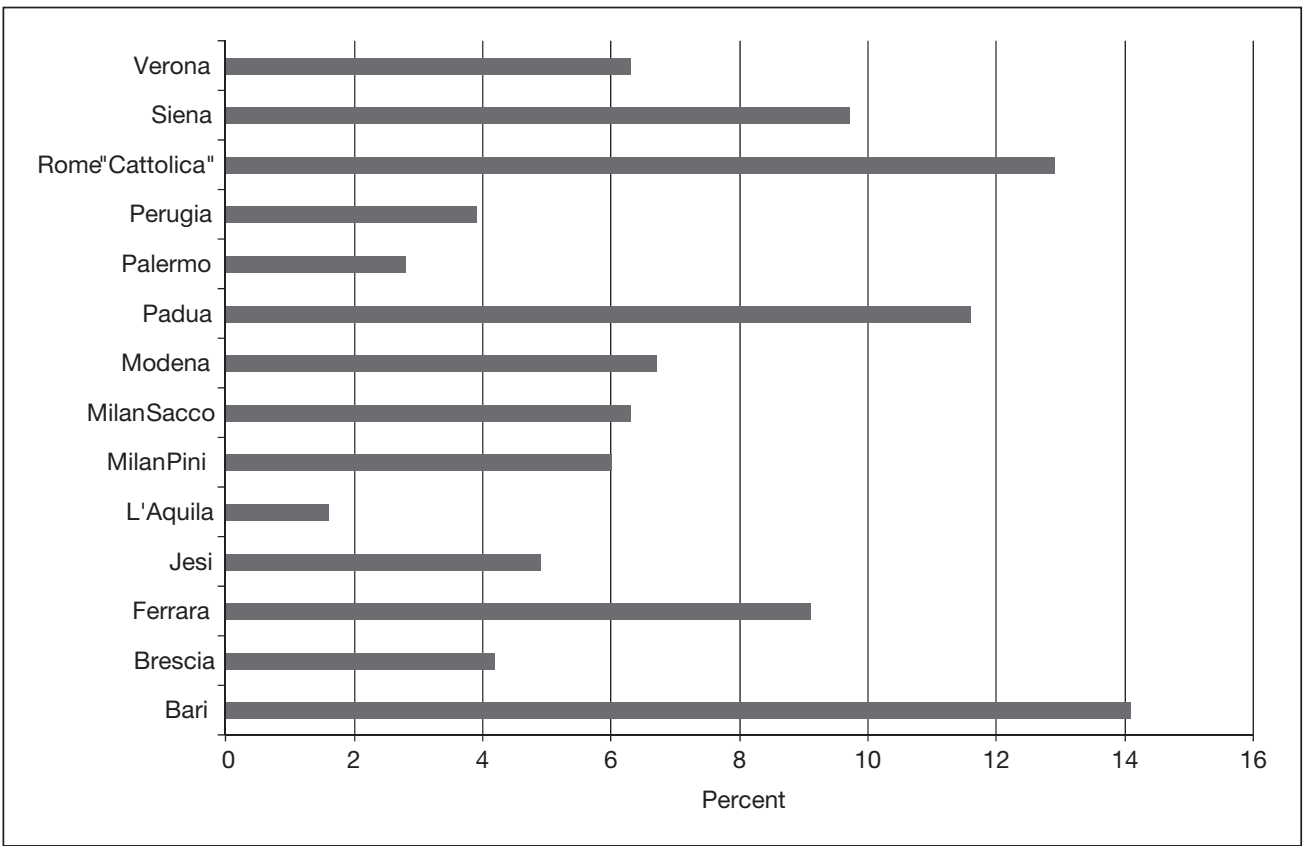


Table II - Enrolment diagnosis of GISEA patients as of March 2010.

\begin{tabular}{|l|c|c|c|c|}
\hline Disease & No. of patients & $\begin{array}{c}\text { Percentage of total } \\
\text { patients }\end{array}$ & $\begin{array}{c}\text { Mean age at } \\
\text { diagnosis, years }\end{array}$ & Mean BMI \\
\hline Enteropathic arthritis & 14 & 0.3 & 43 & 27.78 \\
\hline Psoriatic arthritis & 833 & 16.2 & 49 & 26.96 \\
\hline Rheumatoid arthritis & 3494 & 67.9 & 53 & 25.34 \\
\hline Reactive arthritis & 4 & 0.1 & 60 & n.d. $^{*}$ \\
\hline Enthesopathic arthritis & 64 & 1.2 & 47 & 28.33 \\
\hline Ankylosing spondylitis & 493 & 9.6 & 43 & 25.48 \\
\hline Undifferentiated spondylo-arthritis & 243 & 4.7 & 47 & 26.77 \\
\hline Total & 5145 & 100 & & \\
\hline
\end{tabular}

${ }^{*}$ Not determined.

Table III - Concurrent therapy.

\begin{tabular}{|l|c|}
\hline Therapy & Patients (\%) \\
\hline DMARDs \\
\hline Azathioprine & $53(0.8)$ \\
\hline Cyclosporine & $281(4.2)$ \\
\hline Hydroxychloroquine & $646(9.8)$ \\
\hline Leflunomide & $724(10.9)$ \\
\hline Methotrexate & $4294(64.9)$ \\
\hline Penicillamine & $2(-)$ \\
\hline Sulfasalazine & $533(8.1)$ \\
\hline Gold salts 81 & $(1.2)$ \\
\hline Corticosteroids & $37(0.7)$ \\
\hline Betamethasone & $106(2.1)$ \\
\hline Deflazacort & $3180(62.0)$ \\
\hline Methylprednisolone & $1809(35.2)$ \\
\hline Prednisone
\end{tabular}

written consent form is signed by each patient upon entry in the registry.

\section{RESULTS}

The GISEA registry is the largest existing database in Italian rheumatic patients.

As of March 2010, 5.145 patients had been enrolled by the 14 GISEA centres (Fig. 1) of whom $1.927(35.8 \%)$ had been treated for at least three years.

\section{Demographics, diagnosis and comorbidities}

The database includes 3.494 patients (67.9\%) with RA, 833 (16.9\%) with PsA, $493(9.6 \%)$ with AS, and $307(5.9 \%)$ with undifferentiated spondylo-entheso arthritides (Tab. II). The female/male ratio is 2.54 (3703:1457), and the majority of pa-
Table IV - First line biological therapy taken by GISEA as of March 2010.

\begin{tabular}{|l|c|c|}
\hline $\begin{array}{l}\text { Biological } \\
\text { therapy }\end{array}$ & No. of patients & $\%$ \\
\hline Abatacept & 18 & 0.4 \\
\hline Adalimumab & 1233 & 25.8 \\
\hline Anakinra & 88 & 1.8 \\
\hline Etanercept & 1917 & 40.1 \\
\hline Infliximab & 1462 & 30.5 \\
\hline Rituximab & 68 & 1.4 \\
\hline Total & 4786 & 100 \\
\hline
\end{tabular}

tients are aged 46-65 years (overall mean age 53 years, range 16-88 years). The most frequent comorbidities are hypertension (1.091 patients, 20.6\%), thyroid diseases (416, 7.9\%), and ischemic cardiopathy, gastrointestinal illnesses (diverticuli, gastritis, irritable colon disease, gastroesophageal reflux disease) and diabetes (nearly 270 patients each, about $5 \%$ ). The pattern of comorbidities observed in our cohort seems to resemble those reported in other RA patients populations treated with biological agents (31).

\section{Conventional and biological therapies}

Table III shows that methotrexate is the most frequently chosen DMARD to combine with biological therapy (4.294 patients, $64.9 \%$ ), followed by leflunomide (724, 10.9\%), hydroxychloroquine (646, $9.8 \%)$ and sulfasalazine $(533,8.1 \%)$. Of the corticosteroids, methylprednisolone is concomitantly prescribed for 3.180 patients (62\%) and prednisone for 1.809 (35.2\%).

As first-line biological therapy, 1.917 patients $(40.1 \%)$ received etanercept, 1.462 
Table V - Treatment survival (months).

\begin{tabular}{|l|c|c|c|c|}
\hline & \multicolumn{2}{|c|}{ First treatment } & \multicolumn{2}{c|}{ Second treatment } \\
\hline & No. of patients & Mean \pm SD & No. of patients & Mean \pm SD \\
\hline Abatacept & 17 & $4.59 \pm 6.20$ & 7 & $10.3 \pm 4.54$ \\
\hline Adalimumab & 977 & $12.9 \pm 14.4$ & 126 & $23.5 \pm 15.7$ \\
\hline Anakinra & 73 & $15.9 \pm 19.4$ & 14 & $31.7 \pm 20.6$ \\
\hline Etanercept & 1349 & $13.8 \pm 16.9$ & 255 & $27.9 \pm 18.4$ \\
\hline Infliximab & 1079 & $16.5 \pm 21.3$ & 63 & $19.6 \pm 15.5$ \\
\hline Rituximab & 48 & $3.48 \pm 6.87$ & 19 & $18.6 \pm 17.5$ \\
\hline
\end{tabular}

Table VI - Reason for stopping biological therapy in GISEA patients as of March 2010.

\begin{tabular}{|l|c|}
\hline Reason & $\%$ \\
\hline Death & 1.2 \\
\hline Drop out/lost to follow-up & 13.2 \\
\hline Adverse event & 29.8 \\
\hline Primary drug inefficacy & 32.9 \\
\hline Secondary loss of efficacy & 13.8 \\
\hline Remission & 23.6 \\
\hline Other & 5.5 \\
\hline
\end{tabular}

(30.5\%) infliximab and $1.233(25.8 \%)$ adalimumab (Tab. IV). As expected, data on patients treated with Etanercept, Infliximab and/or Adalimumab predominate because they were introduced first into clinical practice. However, the number of patients treated with more recent therapies is increasing.

All of the drugs that have been on the market for more than five years (anakinra, infliximab, etanercept and adalimumab) show comparable survival on treatment (Tab. V), which is longest in the case of etanercept and infliximab although the difference is not statistically significant. This trend is quite in line with previous published data from other European registries (32, 33). When used as first-line therapy, the mean duration of treatment with etanercept is 13.8 months (1.349 patients) and that of infliximab is 16.5 months (1.079 patients); when used as second-line therapy, etanercept once again shows the longest treat-

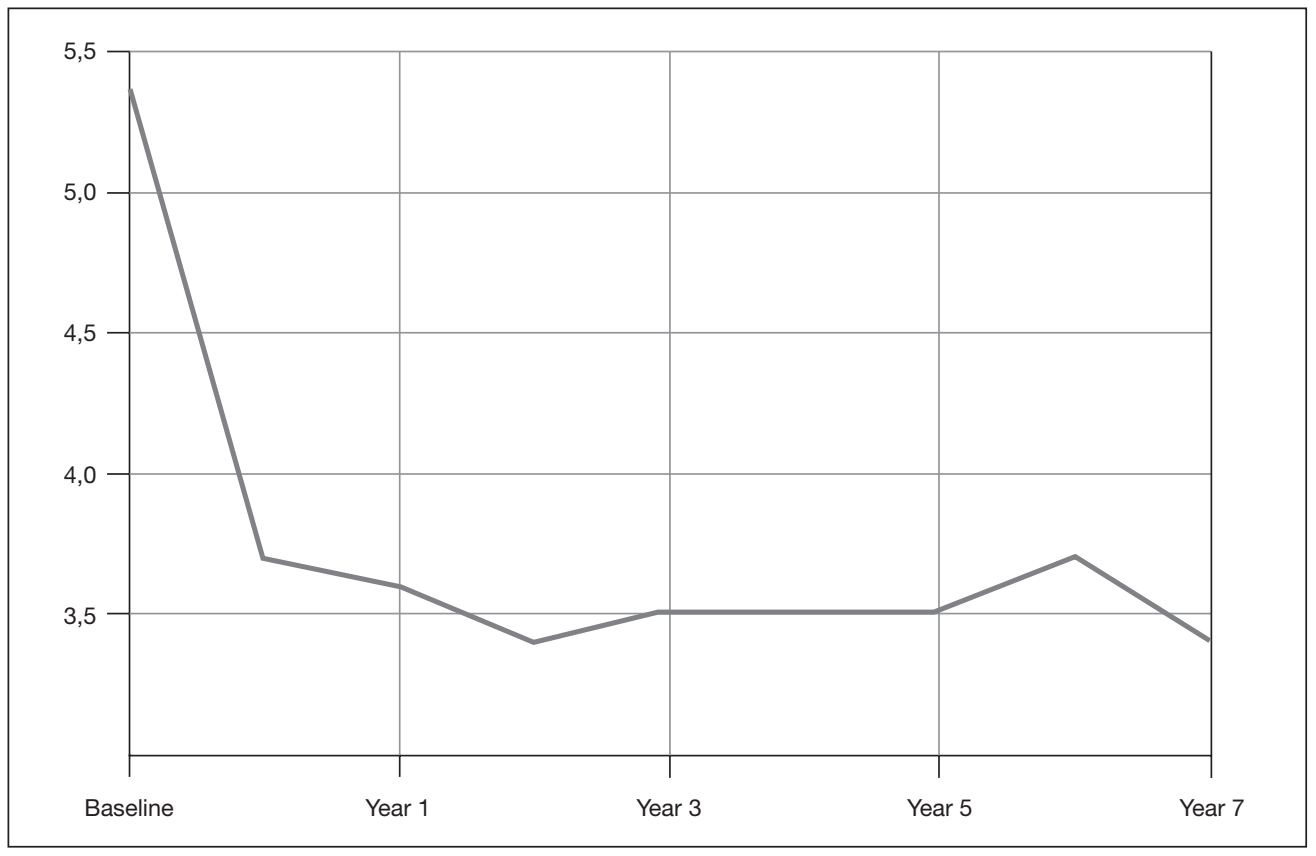

Figure 2 - Disease activity assessment (DAS-28) in 3494 GISEA patients with RA treated with biological agents in GISEA database (mean values). 


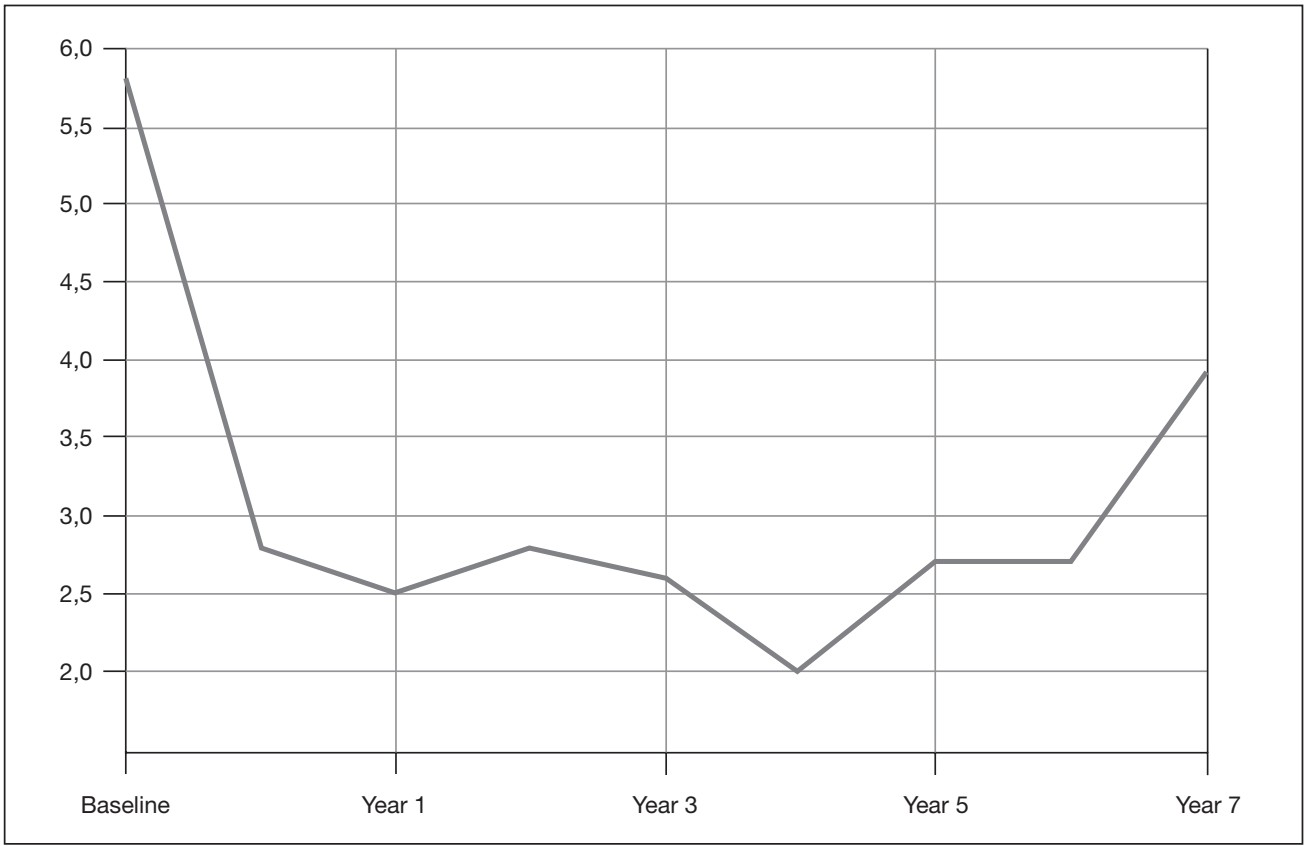

Figure 3 - Disease activity assessment (BASDAl score) in GISEA patients with spondylo-arthritis treated with biological agents (mean values).

ment survival (a mean treatment duration of 27.9 months in 255 patients).

Table VI shows the main reasons for stopping biological treatment: drug inefficacy in $32.9 \%$ of the cases, adverse events in $29.8 \%$, secondary inefficacy (loss of efficacy) in $13.8 \%$, drop out/lost to follow-up in $13.2 \%$, and disease remission in $3.6 \%$. The low percentage of remission is probably due to the large number of patient with late disease and multiple comorbidities constituting the "real life" population enrolled in the study. Overall, the observed rates of treatment discontinuation are comparable with those reported in other registries, ranging between $21-38 \%$ for adverse events $(34,32)$ and between $22-36 \%$ for inefficacy $(34,35)$.

On the basis of the trend of the DAS-28 scores in the RA patients, disease activity was significantly reduced during the first six months of treatment, and then remained generally stable during seven years of follow-up (Fig. 2). In the AS patients, the BASDAI scores also significantly decreased during the first six months of treatment, but then fluctuated more over time (Fig. 3). One possible ex- planation for this observation can be related to the demonstrated efficacy of antiTNF agents on inflammatory bone edema in AS patients, which leads to a significant improvement in signs and symptoms during the first months of therapy. On the contrary, anti-TNF agents do not seem to inhibit the bone formation associated with AS $(36,38)$, although further research is clearly needed to assess their full impact on radiographic progression in AS. However, the interpretation of these data may be limited by the use of mean values in the absence of stratification by drug or baseline disease activity.

A total of 2.926 adverse events have so far

Table VII - Adverse events in GISEA patients as of March 2010.

\begin{tabular}{|l|c|c|}
\hline \multicolumn{1}{|c|}{ Adverse event } & N & $\%$ \\
\hline Cardiovascular events & 93 & 3.25 \\
\hline Infections & 1161 & 39.68 \\
\hline Neoplasms & 48 & 1.64 \\
\hline Biological reactions & 249 & 8.51 \\
\hline Increased transaminases & 132 & 4.51 \\
\hline Other & 1241 & 42.41 \\
\hline Total (all) & 2926 & 100 \\
\hline
\end{tabular}


been observed, with 1.171 patients (22\%) reporting at least one adverse event. Infections have been reported by 1.161 patients (39.68\%) (Tab. VII).

\section{CONCLUSIONS}

With 5.145 treated patients, the GISEA database that we have constructed and maintained over the last two years provides the largest Italian system for monitoring the safety and clinical efficacy of biological therapies, and survival on treatment in a number of rheumatic diseases. GISEA is an important resource for tracking the evolution of disease activity in treated patients and, as it provides access to "real life" data concerning therapeutic outcomes in patients with long-standing diseases and various comorbidities that may affect the efficacy of treatment, our registry provides a powerful and useful means of improving patient management.

To this end it entered into the METEOR network (www.meteorfoundation.com; http://meteorfoundation.com/Portals/0/ Current $\% 20$ Country\%20Leads.pdf) pro- viding METEOR a substantial percentage of all the patients registered at the International Level. It is clear that the chance of confronting ourselves with other clinical approaches worldwide will represent a challenge but certainly also an enrichment.

The database also offers insights into the cost effectiveness of these therapies and allows the development of rational and costeffective strategies for their use.

Prescription practices are influenced by efficacy, safety, physician preferences and, increasingly, also pharmaco-economic considerations. The relatively high cost of biological therapies in comparison with traditional DMARDS justifies close scrutiny of their efficacy and safety not only in the carefully selected populations of controlled clinical trials, but also in routine practice (something that is becoming increasingly important to healthcare management agencies).

We are also confident that a full analysis of our data will provide insights into the critical early phase of rheumatic diseases and make it possible to identify clinical profiles that predict treatment responsiveness.

\section{SUMMARY}

The GISEA registry is an independent database that was established by the Italian Group for the Study of Early Arthritis (GISEA) in 2008, funded by the Italian Association of Rheumatic Patients (ANMAR - ONLUS). In line with the network's epidemiological strategy, the initial protocol was designed to collect long-term follow-up data concerning patients with rheumatic diseases treated with biological agents in order to investigate the realworld characteristics in terms of disease activity, comorbidities and survival on treatment. We here describe the design and methodology used to collect patient data. Information concerning demographics, disease activity, treatment changes (including the reasons for changing and the duration of each therapy), concomitant therapies and adverse events is available to all the members of the study groups by means of a web-based interface that allows queries and the presentation of numerical data, as well as graphics to illustrate trends. Fourteen Italian rheumatology centres have contributed patients to the database which, at the time writing, includes 5145 patients (72\% women) with a mean age of 53 years (range 16-88). The initial diagnoses were rheumatoid arthritis (3494 patients, $67.9 \%)$, psoriatic arthritis (833, 16.2\%), ankylosing spondylitis (493, 9.6\%), undifferentiated spondylo-arthritides (307, 5.9\%), enteropathic arthritis $(14,0.3 \%)$ and spondylitis following reactive arthritis (4, 0.1\%). These patients have been followed for up to 10 years, and 1927 (35.8\%) have been treated for at least three years. The biological treatments received include etanercept, infliximab, anakinra, adalimumab, abatacept, rituximab and tocilizumab. A total of 2926 adverse events have been observed, with 1171 patients $(22 \%)$ reporting at least one.

Analysis of the accumulated data will provide insights into the critical early phase of the studied arthritides, and enable us to identify the clinical and laboratory profiles that may predict responsiveness to a specific therapy.

Parole chiave: Farmaci biologici, studio osservazionale, pratica clinica. Key words: Biological agents; observational study; real-world practice. 


\section{REFERENCES}

1. Waldburger JM, Firestein GS. Garden of therapeutic delights: new targets in rheumatic diseases. Arthritis Res Ther 2009; 11: 206.

2. van Vollenhoven RF. Treatment of rheumatoid arthritis: state of the art 2009. Nat Rev Rheumatol 2009; 5: 531-41.

3. Strand V, Sokolove J. Randomized controlled trial design in rheumatoid arthritis: the past decade. Arthritis Res Ther 2009; 11: 205.

4. Pincus T, Sokka T. Should contemporary rheumatoid arthritis clinical trials be more like standard patient care and vice versa? Ann Rheum Dis 2004; 63 (2 Suppl): ii32-ii39.

5. Sokka T, Pincus T. Eligibility of patients in routine care for major clinical trials of antitumor necrosis factor alpha agents in rheumatoid arthritis.Arthritis Rheum 2003; 48: 313-8.

6. Sokka T, Pincus T. Most patients receiving routine care for rheumatoid arthritis in 2001 did not meet inclusion criteria for most recent clinical trials or American College of Rheumatology criteria for remission. J Rheumatol 2003; 30: 1138-46.

7. Pincus T, Stein CM. Why randomized controlled clinical trials do not depict accurately long-term outcomes in rheumatoid arthritis: some explanations and suggestions for future studies. Clin Exp Rheumatol 1997; 15 (17 Suppl): S27-S38.

8. Pincus T. Limitations of randomized clinical trials in chronic diseases: explanations and recommendations. Adv Mind Body Med 2002; 18: 14-21.

9. van Vollenhoven RF, Askling J. Rheumatoid arthritis registries in Sweden. Clin Exp Rheumatol 2005; 23 (5 Suppl 39): S195-S200.

10 . Westerholm B. The rationale for a post-marketing surveillance. Hum Reprod 1987; 2: 41-4.

11. Askling J, Fored CM, Geborek P, Jacobsson LT, van Vollenhoven R, Feltelius N, Lindblad $\mathrm{S}$, Klareskog L. Swedish registers to examine drug safety and clinical issues in RA. Ann Rheum Dis 2006; 65: 707-12.

12. Moll JMH, Wright V. Psoriatic arthritis. Semin Arthritis Rheum 1973; 3: 55-78.

13. Van der Linden S, Valkenburg HA, Cats A. Evaluation of diagnostic criteria for ankylosing spondylitis: a proposal for modification of the New York criteria. Arthritis Rheum 1984; 27: 361-8.

14. Smolen JS, Breedveld FC, Eberl G, Jones I, Leeming M, Wylie GL, et al. Validity and reliability of the 28 joint count for the assessment of rheumatoid arthritis activity. Arthritis Rheum 1995; 38: 38-43.

15. Furst DE, Breedveld FC, Kalden JR, et al. Updated consensus statement on biological agents for the treatment of rheumatic diseases, 2007. Ann Rheum Dis. 2007; 66 (Suppl 3): iii2-22.
16. Valesini G, Montecucco C, Cutolo M. AntiTNF treatment for rheumatoid arthritis. Clin Exp Rheumatol 2006; 24: 413-23.

17. Salvarani C, Olivieri I, Cantini F, et al. Raccomandazioni per il corretto uso degli agenti biologici bloccanti il TNF $\alpha$ nell'artrite psoriasica. Reumatismo 2004; 56: 133-38.

18. Olivieri I, Salvarani C, Cantini F, et al. Raccomandazioni per l'inizio del trattamento con anti-TNF $\alpha$ nella spondilite anchilosante. Reumatismo 2004; 55: 220-23.

19. Prevoo ML, van Gestel AM, van T Hof MA, van Rijswijk MH, van de Putte LB, van Riel PL. Remission in a prospective study of patients with rheumatoid arthritis. American Rheumatism Association preliminary remission criteria in relation to the disease activity score. Br J Rheumatol 1996; 35: 1101-5.

20. Smolen JS, Breedveld FC, Schiff MH et al. A Simplified Disease Activity Index for rheumatoid arthritis for use in clinical practice. Rheumatology 2003; 42: 244-57.

21. Aletaha D, Smolen J. the Simplified Disease Activity Index (SDAI) and the Clinical Disease Activity Index (CDAI): a review of their usefulness and validity in rheumatoid arthritis. Clin Exp Rheumatol 2005; 23 (Suppl. 39): S100-108.

22. Felson DT, Anderson JJ, Boers M et al. American College of Rheumatology. Preliminary definition of improvement in rheumatoid arthritis. Arthritis Rheum 1995; 38: 727-35.

23. Fries JF. The hierarchy of quality-of-life assessment, the Health Assessment Questionnaire (HAQ), and issues mandating development of a toxicity index. Control Clin Trials. 1991 Aug; 12 (4 Suppl): 106S-117S.

24. Anderson JJ, Baron G, van der Heijde D, Felson DT, Dougados M. Ankylosing Spondylitis Assessment Group preliminary definition of short-term improvement in ankylosing spondylitis. Arthritis Rheum 2001; 44: 1876-86.

25. Garrett S, Jenkinson T, Kennedy LG, Whitelock H, Gaisford P, Calin A. A new approach to defining disease status in ankylosing spondylitis: the Bath Ankylosing Spondylitis Disease Activity Index. J Rheumatol 1994; 21: 2286-91.

26. Calin A, Garrett S, Whitelock H, Kennedy LG, O'Hea J, Mallorie P, et al. A new approach to defining functional ability in ankylosing spondylitis: the development of the Bath Ankylosing Spondylitis Functional Index. J Rheumatol. 1994; 21: 2281-5.

27. Jenkinson TR, Mallorie PA, Whitelock HC, Kennedy LG, Garrett SL, Calin A. Defining spinal mobility in ankylosing spondylitis (AS). The Bath AS Metrology Index. J Rheumatol. 1994; 21: 1694-8.

28. Heuft-Dorenbosch L, Spoorenberg A, van Tubergen A, Landewé R, van ver Tempel H, Mielants $\mathrm{H}$, et al. Assessment of enthesitis in an- 
kylosing spondylitis. Ann Rheum Dis. 2003; 62: 127-32.

29. Fredriksson T, Pettersson U. Severe psoriasis - oral therapy with a new retinoid. Dermatologica 1978; 157: 238-44.

30. Harrison MJ, Davies LM, Bansback NJ, Ingram M, Anis AH, Symmons DP. The validity and responsiveness of generic utility measures in rheumatoid arthritis: a review. J Rheumatol 2008; 35: 592-602.

31. Hyrich K, Symmons D, Watson K, Silman A; BSRBR Control Centre Consortium; British Society for Rheumatology Biologics Register. Baseline comorbidity levels in biologic and standard DMARD treated patients with rheumatoid patients: results from a national patient register. Ann Rheum Dis 2006; 65: 895-8.

32. Hetland ML, Christensen IJ, Tarp U, Dreyer L, Hansen A, Hansen IT, et al. Direct comparison of treatment responses, remission rates and drug adherence in patients with rheumatoid arthritis treated with adalimumab, etanercept or infliximab. Arthritis Rheum 2010; 62: 22-32.

33. Markenson JA, Gibofsky A, Palmer WR, Keystone EC, Schiff MH, Feng J, et al. Persistence with anti-tumor necrosis factor therapies in patients with rheumatoid arthritis: observations from the RADIUS registry. J Rheumatol 2011; 38: 1273-81.
34. Soliman MM, Ashcroft DM, Watson KD, Lunt M, Symmons DP, Hyrich KL. Impact of concomitant use of DMARDs on the persistence with anti-TNF therapies in patients with rheumatoid arthritis: results from the British Society for Rheumatology Biologics Register. Ann Rheum Dis 2011; 70: 583-9.

35. Carmona L, Gómez-Reino JJ; BIOBADASER Group. Survival of TNF antagonists in spondylarthritis is better than in rheumatoid arthritis. Data from the Spanish registry BIOBADASER. Arthritis Res Ther 2006; 8: R72.

36. Van der Heijde D, Salonen D, Weissman B, Landewé R, Maksymowych WP, Kupper H, et al. Assessment of radiographic progression in the spines of patients with ankylosing spondylitis with adalimumab for up to 2 years. Arthritis Res Ther 2009; 11: R127.

37. Van der Heijde D, Landewé R, Einstein S, Ory $\mathrm{P}$, Vosse D, Ni L, et al. Radiographic progression of ankylosing spondylitis after up to 2 years of treatment with etanercept. Arthritis Rheum 2008; 58: 1324-31.

38. Van der Heijde D, Landewè R, Baraliakos X, Houben H, van Tubergen A, Williamson P, et al. Radiographic findings following 2 years of infliximab therapy in patients with ankylosing spondylitis. Arthritis Rheum 2008; 58: 3063-70. 